\title{
食道ファイバースコープによる異物の摘出
}

（特に異物鉗子及び采切り鉗子について）

\author{
*遠藤光夫, 矢沢知海, 鈴木 茂, 中山恒明 \\ **竹本忠良
}

\section{Removal of the Foreignbody form the Esophagus Using Esophagofiberscope.}

Mitsuo Endo, M.D. et al.

Institute of Gastroenterology,

Tokyo Women's Medical College.

\begin{abstract}
Recent esophagofiberscope has almost complete capabilities for the diagnostic fields of the esophageal diseases. But its contribution to the th.erapeutic fields has rarely been made. For the removal of the foreignbody from the esophagus and stomach, a kind of special forceps was devised. This was inserted through the biopsy channel of the esophagofiberscope. The foreigntodies were captured under visual control and taken off with the fiberscope altogether. The demonstration of the forceps and some clinical results will be reported. Sometimes the silk suture could be found at the stoma after surgery. For the removal of it the special forceps, named "suture-cutting forceps", was newly devised. This forceps was inserted through the biopsy channel of the esophagofiberscope and able to cut and take off the suture under visual control.
\end{abstract}

\section{I はじめに}

食道鏡検査に柔軟な食道ファイバースコープ が応用されてから既に数年になる。その間器械 の改良進歩はめざましく, 診断面についてはほ ほ满足すべき成績をあげうるようになつてき た。しかし治療面については従来余り顧りみら れず専ら直達鏡に委祇られてきた。直達鏡によ る異物の摘出については諸先達より数多くの教 えがあり, 鐁子の工夫, 摘出技術の改良と, 既 に完成されたといえると思う。

一方，一般の内科，外科医の間でも剔出にそ れ程困難でない異物に遭遇することは案外に多 い。われわれのところでも食道癌, 食道潰瘍,

東京女子医大 消化器病センター
*外科
**内科

食道手術の術後など食道に狭窄のある患者に接 する機会が多く, 食物塊, 薬のカプセル, 薬の P T P 包装, 又, 術後吻合部の遺残縫合采など の異物をみることが時にある。従来は食道ファ イバースコープで診断した後に再び直達鏡を插 入除去していたが, 食道ファイバースコープで の直視下に摘出できればと思い，领子について 2,3 の検討をおこなつたので臨床経験とあわせ て報告する。

\section{II 異 物 鉗子}

食道ファイバースコープの生検热子孔を利用 するため, 外管の径は生検鈾子とほほ同じく外 径 $2.2 \mathrm{~mm}$ のらせん状のワイヤーを用いた。先 端部 $5 \mathrm{~mm}$ 程を金属環にし, 鉗子は外管より押 出されると自身の弾性で先端部が $8 \mathrm{~mm}$ から 15 $\mathrm{mm}$ に開く。先端部の形状は鉤状, 麦粒状, 三 
気食会報 -22 巻

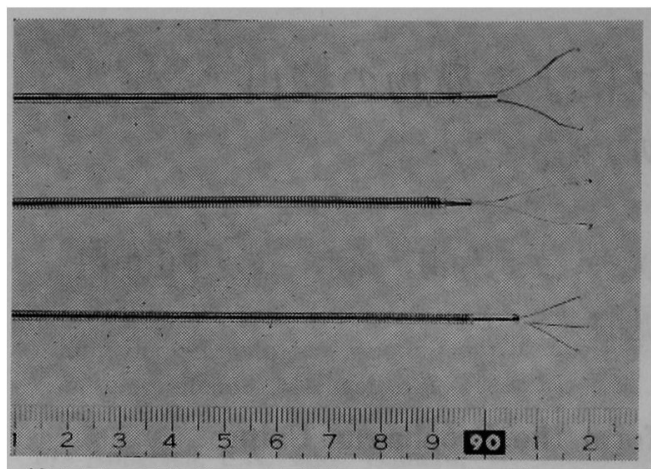

第1図異物鉜子の先端部, 上より鈎状, 麦粒 状, 三本銁

本鉤とし，それぞれ異物の種類によつて使いわ ける(第 1 図)。手許の操作部は生検鉜子と同じ く金属の輪を把持子とし，つまみをはさんで前 後運動させることで先端部が開閉するようにし た。鉤状鉗子の把持力は， $1 \mathrm{~kg}$ の分銅をはさん で吊下げ，更に振動させることもできた。鎙子 は食道ファイバースコープの銝子孔より挿入す る(第 2 図)。異物を把持する際，構造上鉗子部

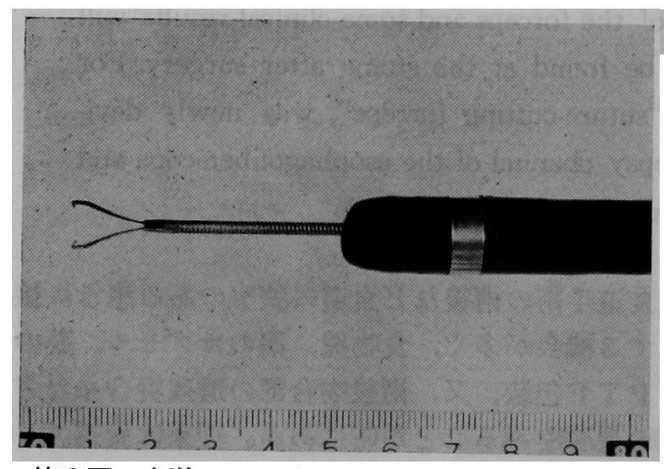

第 2 図 食道ファイバースコープ（E F）の生検 銝子孔より銁状の異物釷子を㨉入したと ころ

が後退するので, 外管を前進するよらに操作し ながら閉じていくようにする。異物を把持した らできるだけスコープ先端キャップ部に密着さ せるようにし，スコープと一しよに抜去する。 操作時の前処置としては通常の食道ファイバ ースコープ検査と同じであるが, あらかじめ異 物の予想されるときは咽頭の表面麻酔をより丁 寧にやるようにしている。

症例 67才, 女性, 5 年前噴門癌にて他病院 で手術をらけ, 経過は順調であつたが梅干のた

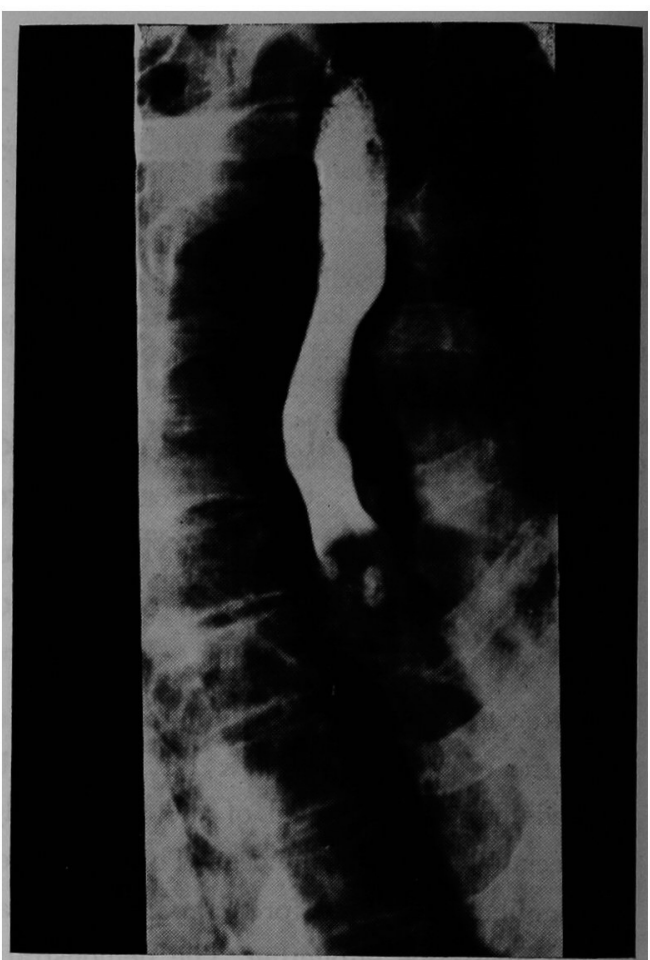

第3図 A

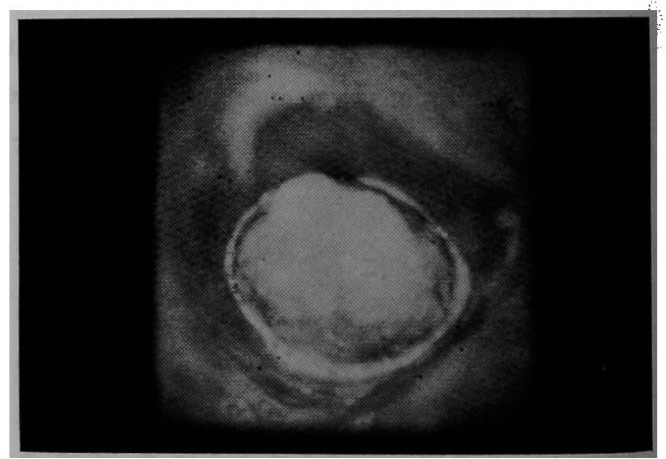

第3図 B

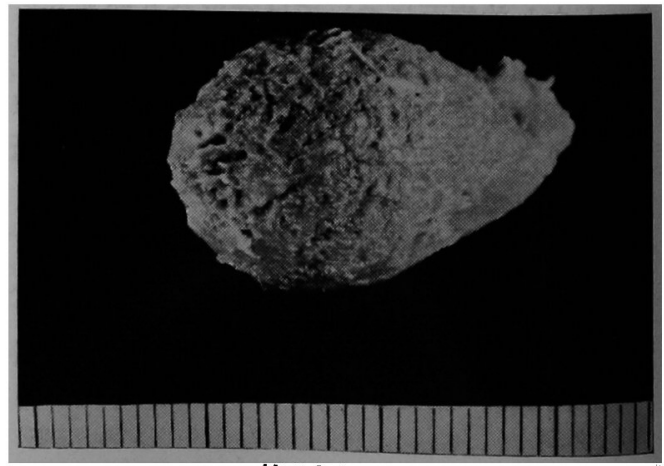

第3図 C 
ねを誤つてのみこんでから食物の器下障害があ り来院した。X線上, 下部食道に近くバリウム の通過障害と陰影欠損を認め(第 3 図A), 食道 ファイバースコープ (EF) でバリウムの附着し た異物を認めた(第 3 図 $\mathrm{B})$ 。鈎状鍀子で把持し 摘出したが，大きさ $2.3 \times 1.6 \mathrm{~cm}$ であつた（第 3 図C)。摘出後再插入して検查したが，下部 食道で狭窄がみられ，この狭窄部分の奥に吻合 部がみられ，X線写真での所見がうなづけた。 又, 異物の圧迫によるびらん, 出血班もみられ たが, 摘出による食道入口部附近の影響はみら れなかつた。

\section{III 糸切り鉗子}

消化管吻合部に遣残縫合系のみられることが ある。特に連続縫合をおこなつた場合に塊状 に，又尾をひいて垂れ下がつていたり，ループ 状になつていたりして目立つてくる。普通は内 側の全層縫合（アルベルト縫合）のものが多い が，外側の墏膜縫合 (レンベ:ルト縫合)のもの も内腔へでてくる。これは一端がかたく組織内 に埋没されていて引張つただけでは除去しにく いものが多い。このような遺残縫合系の除去に 采切り鐁を工夫した。

外径 $2.0 \mathrm{~mm}$ のらせん型のワイヤーを本体と し, 先端硬性部分は長さ $1.2 \mathrm{~cm}$, 径 $2.5 \mathrm{~mm}$ で, 中央の金属板とうけ皿の溝とが鈇のようになつ て禾を切断する。開いたとき丸くへこみをつ け,ここに系をはさみ, 閉じるとき系が滑つて 脱出しないようにした(第4図)。先端部のシエ ーマ(第5 図) で分かるように釷子の左側は金 属板と下のうけ溝の縁とがお互に密にこすれ合

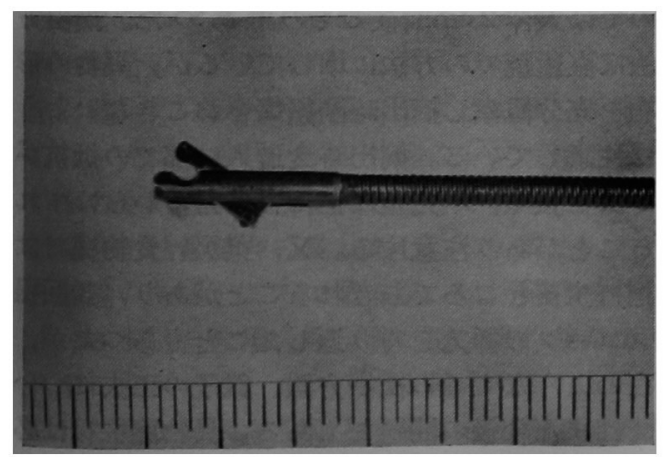

第4图 采切り鉗子先端部（開いたところ）

\section{糸㘮り釷子·先端部シエ一フ}

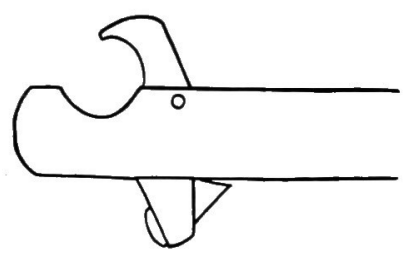

侧 面

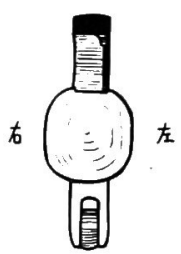

前面
第 5 図

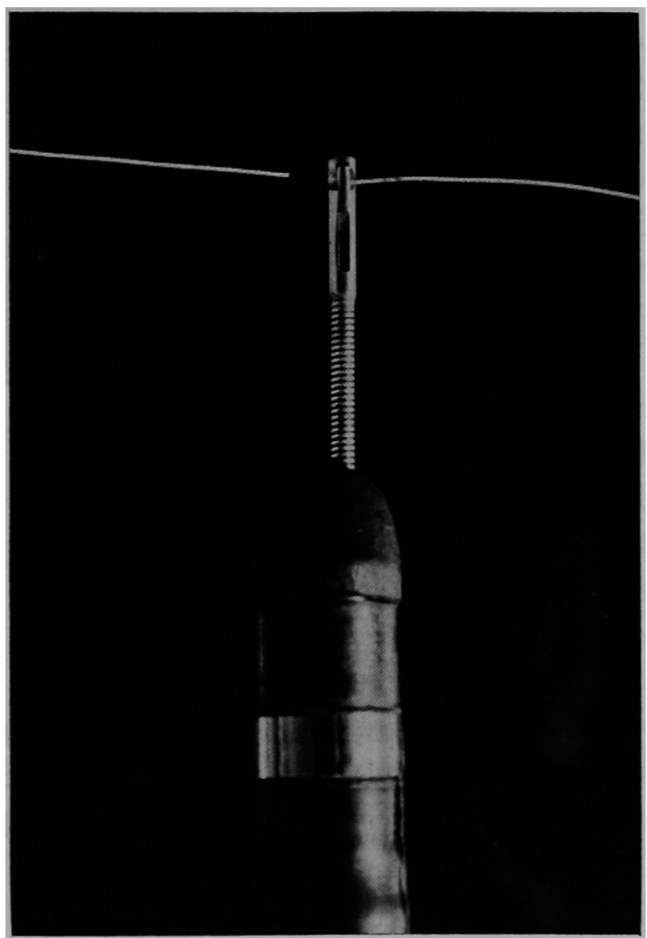

第 6 図 采切り鉜子を E F の生検叙子孔より㨀入 したところ, 切断した糸の右半分はその まま鉬子に把持される

つて鈇の刃の役目をしているが，右側は中央金 属板の縁をけずつてうけ溝の縁との間に僅かの すき間をもたせてはさんだ糸を切断せず把持す るだけの役目をもたせた。このことは実際に采 を切断した際にその右半分をそのまま鉗子と一 しよに除去できるわけである(第 6 図)。食道フ アイバースコープの生検鉗子孔より挿入, 操作 
はすべて直視下におこなつている。

症例 56 才, 男性, 胃癌にて胃全摘, 腹腔内 食道空腸吻合術を施行した。内層の吻合には catgut を用いたのであるが，術後 7 力月目に吻 合部の内腔に長い絹糸が垂れ下がつてみられ た。これは外側のレンベルト縫合の連続縫合采 であるが, その一端は強く深部組織内に埋没固 定され, 引つ張ると吻合部が一しょに動き左肩 部の疼痛を訴えた。そこで系切り銝子を用い出 来るだけ縫合糸をひつぱつた状態で切断した (第 7 図), 他端は組織内にひつこみ, その後 2

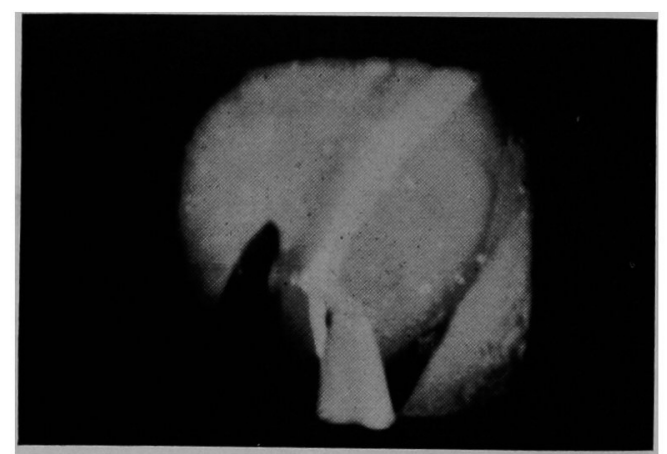

第 7 図 吻合部の遺残縫合采を直視下に切断して いる

回程検查する機会があつたが，吻合部はきれい、 で順調に経過している。

\section{IV 考 案}

現在の食道ファイバースコープについては, その柔軟性のための挿入の容易さ, 患者の苦痛 の少ないという点以外に先端アングル機構によ り食道内に観察盲点がない, 接眼部での拡大視 のため大きさ $2 \sim 3 \mathrm{~mm}$ のものまで診断できる, 直視下生検が容易である, などの長所を備え, 診断面ではほぼ満足のいく成績をあげられるよ うになつた。

一方, 治療面については殆んど顧りみられて いない現状であるが，食道の狭窄をおこす疾患 で食道異物を合併している例は案外に多いもの である。この異物もそれ程大きく苦痛の強いも のばかりではないが, 患者にとつてはやはり嚥 下障害は同じである。従来は診断がついたあ と, 直達鏡を再挿入して除去したが, 食道ファ イバースコープでの観察後そのままひきつづい
ての操作で摘出できるようにしたものである。 まだ大きな，摘出のむづかしい異物には遭遇し ないが，逆に食道内を遊走するようなもの，䓵 下時のみ狭窄部に嵌入するような異物では, 直 達鏡の場合食道の蠕動と粘膜蚠璧にわずらわさ れることがあり，常に送気により食道内腔を拡 張して観察する食道ファイバースコープでの方 が異物をみつけ易く，把持し摘出しやすいとい うことも経験している。

現在までのところ食物塊が最も多く, その他 貨幣状のプラスチック板, 錠剂, 薬の PTP 包 装, 梅干のたねなどである(第 1 表)。大きさは

第 1 表

\begin{tabular}{|c|c|c|c|c|}
\hline \multicolumn{4}{|c|}{$\begin{array}{c}\text { 第 } 1 \text { 表 } \\
\text { 食道ファイバースコープによる摘出 } \\
\text { 食道異物総数 }\end{array}$} & \\
\hline & の 種 類 & 例 & & \\
\hline 食 & 物塊 & \multicolumn{3}{|c|}{24} \\
\hline \multicolumn{2}{|c|}{ 梅干のたね } & \multicolumn{3}{|c|}{1} \\
\hline \multicolumn{2}{|c|}{ レバー } & \multicolumn{3}{|c|}{1} \\
\hline \multicolumn{2}{|c|}{ 豆 } & & & \\
\hline \multicolumn{2}{|c|}{ かにの足 } & \multicolumn{3}{|c|}{1} \\
\hline \multicolumn{2}{|c|}{ いかのくんせい } & \multicolumn{3}{|c|}{1} \\
\hline \multicolumn{2}{|c|}{ 肉 塊 } & \multicolumn{3}{|c|}{6} \\
\hline \multicolumn{2}{|c|}{ な す } & \multicolumn{3}{|c|}{1} \\
\hline \multicolumn{2}{|c|}{ きゆうり } & \multicolumn{3}{|c|}{1} \\
\hline \multicolumn{2}{|c|}{ たくあん } & \multicolumn{3}{|c|}{1} \\
\hline \multicolumn{2}{|c|}{ 識別不明 } & \multicolumn{3}{|c|}{9} \\
\hline \multicolumn{2}{|c|}{ 薬のヒートシール } & \multicolumn{3}{|c|}{1} \\
\hline \multicolumn{2}{|c|}{$\begin{array}{l}\text { プラ } \text { (貨幣大・花弁状) } \\
\text { 将 }\end{array}$} & \multicolumn{3}{|c|}{1} \\
\hline 錠 & 剂 & & & \\
\hline \multicolumn{2}{|r|}{ 計 } & \multicolumn{3}{|c|}{27} \\
\hline
\end{tabular}

食物塊では 4 5 $\mathrm{cm}$ のものもあつたが，固いも のでは大体 $2 \mathrm{~cm}$ 前後のものであつた。摘出方 法は直達鏡での方法に準じているが, 異物の形 態を充分観察し摘出時副損傷をおこさないよう に注意している。摘出時食道入口部での抵抗が やはり強く, 不完全な把持では鉗子からはずれ ることがあり注意する。又, 柔かい食物塊では 把持するところでちぎれることがあり，3 回程 スコープの挿入をくり返したこともあつたが, このようなものの摘出方法, 錤子の工夫につい てはまだ今後の問題でもある。異物除去後は必 ずスコープを再挿入し, 複数個ある異物の残存 
に注意し，同時に原疾患の診断，摘出時の副損 傷の有無の確認をおこなうようにしている。現 在まで偶発症は 1 例も経験していないが安全と 確実さとを常に心掛けて慎重におこなうように している。

更に食道ファイバースコープでの長所は胃内 の異物も同じように摘出可能のことである。第 8 図は誤つて胃内に嚥下された診断用腸紐であ

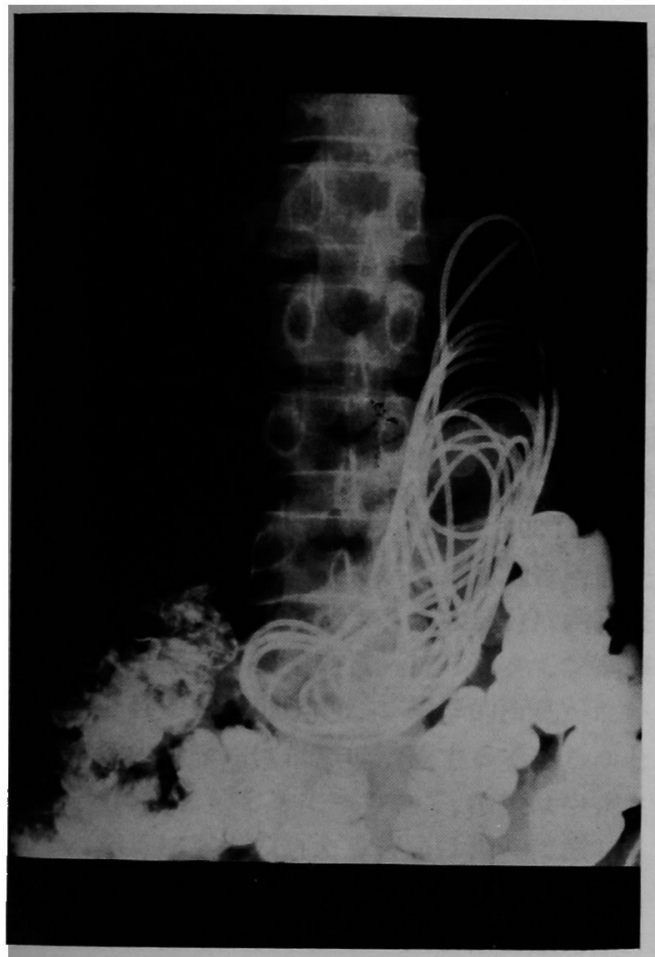

第 8 図

るが，容易に摘出することができた。

術後の遺残縫合采についてはいろいろ問題の あるところである。当初殆んどが全層のアルべ ルト縫合のものであろうと考えられていたが,

全層縫合に catgut を用いるようになつてもみ られ, 先にも子れたが, 外側のレンぶルト縫合 のものも内腔におちてくることが分かつた。連 続縫合と結節縫合の良しあしについてもいろい ろ議論のあるところであるが，結節縫合ではア ルベルト縫合の場合吻合部に縫合采の並んでみ えることがあり，レンベルト縫合のものと考え られる短か、絹禾を除去することもあつて内腔 へ排出されるとい5点では同じだが, 連続縫合
の場合にみられるように大きな塊になつたり， 尾をひいて垂れ下がつたりというようなことは ない。食道再建術々後の吻合部で遺残縫合采附 近を擦過細胞診でみたところ多数の細菌を認め たことがあつた。これは縫合系を除去後は全く 認められなくなつたが, このことから術後 2 週 日以後の遗残縫合糸は積極的に除去するように している。ただ外層のレンべルト縫合のものは 出現する時期ももつとおくれるが，もう少した つてから除去するようにしている。

胃切除術後の吻合部潰場では自験例 8 例中 7

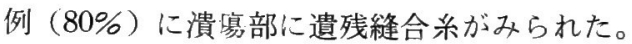
これはすべて全層縫合に絹采を用いたもので少 つて, catgut を用いたものでは僅か 1 例でしか む遗残縫合系はみられなかつた。この吻合部潰 煬例の経過として2例に再手術をおこなつた が，他の例ではいゔれも縫合系を除去し内科的 治療で治癒させ得ているが，長期にわたり治癒 しなかつた例で遺残縫合系を除去後は僅か 2 週 日で洀痕化した例もあつて, 胃切除後の場合で も積極的に除去するようにしている。

胃でも食道でも内層の縫合に catgut 用い 完全に外層の縫合に用いたものとわかる遺残絹 釆についてみてみると, 後者では遺残絹系の組 織へのつきかたがかなり強いことがわかる。例 えば連続縫合采で内層の縫合に用いた絹采が吻 合部に大きく塊のようになつてみえることが㐫 つても生検鉗子でつまみひつぱるだけで簡単に 除去できる。これに反し外層播膜縫合でのもの は一端が内腔に遊離し長く尾をひいているもの でも他端はかたく組織内に埋没されていて，た だつかんで引つ張るだけでは系が弱つていて切 れない限り相当の抵抗をもち, 吻合部が一しよ に引張られたり, 食道の場合左肩部痛などの関 連痛を訴えるようなものまである。稀ではある がループ状になつて組織の厚いトンネルを通つ ているものもあつてただ暴力的に除去するだけ では組織の損傷をおこす危険もある。糸切り鐁 子の使用法で一端がかたく埋没しているもので は、できるだけ引き出して短かく切断するだけ でよい。残つた部分は組織内に引き込まれるが あとの検査でも全く異常をみないことが多い。 又, ループ状のものはその 1 ケ所を切断するだ 


\section{気食会報 -22 巻}

けで，ループがほどけ容易に除去できる。結節 縫合の短かい残系も同じで, 肉芽腫様の隆起と ともにみられることが多いが切断し除去してい る。

\section{$\mathrm{V}$ お りに}

食道鏡検査の大きな役割で, 従来直達鏡に委 ねられていた異物の除去を食道ファイバースコ ープを用いておこなえるよう鉗子の工夫を中心 にのべてみた。食道ファイバースコープが普及 し, 早期癌の発見など診断面に果した役割は大 きいが, 一般の内科, 外科医が時々遭遇する異 物に対して，ファイバースコープでも除去でき るようになれば更に応用面がひろがると思つて いる。勿論現在までに完成された直達鏡による 異物の除去による業績はそのままファイバース コープの場合にもあてはまるものと考え，特に 先人のお示しいただいた貴重な経験, 注意など を深く考え，十分慎重に操作すべきものと思つ ている。
以上，食道ファイバースコープによる異物の 摘出，遺残縫合系の除去など鉗子の工夫を中心 にのべてきた。まだ鈿子の改良適応など問題点 ものこされているが, 食道ファイバースコープ の治療面への応用の第一歩として報告した次第 である。

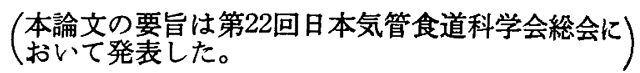

\section{文献}

1）河田政一, 他：食道異物症, 臨床耳鼻咽喉科全 書第 3 巻第 2 冊, 596頁, 金原出版, 1965

2）小野譲：気道及食道の異物, 第15回日本医学会 総会講演 (24群, 75番)，1958

3）山川強四郎：気道及食道の異物, 第15回日本医 学会総会講演 (24群, 75番), 1958

4）久保隆一：食道の異物, 気管食道科学, 475頁, 医学書院, 1968

5）遠藤光夫, 他：外科領域における診断法の進 歩, 消化器系 (食道, 胃, 大腸) の早期癌を中心 として，臨床外科， $26: 107,1971$

6）遠藤光夫, 他：上部消化管吻合部における遺残 縫合系の問題 (内視鏡的立場から), 臨床外科, $26: 391,1971$ 